\title{
MAPPING THE DISTRIBUTION OF SALTWATER CROCODILE (Crocodylus porosus) AND RISKS OF HUMAN-CROCODILE CONFLICTS IN SETTLEMENTS AROUND KUTAI NATIONAL PARK, EAST KALIMANTAN
}

\author{
RAMDANI ${ }^{*}$, MIRZA DIKARI KUSRINI, AND LILIK BUDI PRASETYO \\ Department of Forest Resources Conservation and Ecotourism, Faculty of Forestry, IPB Campus Dramaga, Bogor \\ 16680, Indonesia
}

*Email: ramdanimanurung15@gmail.com

\author{
Accepted September 26, 2020 / Approved February 26, 2021
}

\begin{abstract}
Human-crocodile conflicts $(\mathrm{HCC})$ are problems affecting crocodile conservation. Scientific publications on crocodile attack cases in Indonesia are few with low validation which hinder optimal conflict mitigation efforts. The estuarine river of Kutai National Park is a natural habitat for saltwater crocodiles and mostly nearby dense settlements. This study aims to map the distribution of saltwater crocodiles and potential conflicts in the Kutai National Park area. To predict the distribution of saltwater crocodiles, we used Maximum Entropy MAXENT with its environmental predictors i.e. slope, altitude, distance from shore, distance from river, temperature, and habitat types (mangrove forest, freshwater swamp, and shrubs). MAXENT prediction showed that elevation was the most influential variable with AUC (Average Under Curve) value of 0.952. Settlements with activities occurring within one kilometer from the river and those adjacent to coastal areas proved to be the highest in human conflicts with crocodiles.
\end{abstract}

Key words: conflict, crocodile, human, MAXENT

\section{INTRODUCTION}

Human-wildlife conflict is one of the threats to the decreasing population of some species of wildlife. Competition between humans and wildlife for shared limited resources in an area has brought losses both to the wildlife and humans (Dickman 2010). Negative interaction such as in the case of tiger-human conflicts can occur due to competition for resources (Nugraha and Sugardjito 2009).

Reptiles often cause death in human-wildlife conflicts. According to reports from the WHO (World Health Organization), in Southeast Asia, South Asia, and Sub-Saharan Africa countries, there are 421 thousand snakebites cases per year which often result in injury and death (Subroto and Lismayanti 2017). Besides snakes and komodos, crocodiles are also recorded as a type of reptile that often negatively interacts with humans (Longkumer et al. 2017). This negative interaction often occurs in conservation areas adjacent to settlements, such as in the case of human-komodo conflicts that happened in Komodo National Park, especially in Komodo Village and Rinca Village (Ramadhani 2018).

The problem that affects crocodile conservation is human-crocodile conflict. The most common causes of crocodile attacks are the decrease in the natural habitat of crocodiles, the decrease in crocodile prey populations, and high human activities in the crocodile home range (Webb et al. 2010). In addition, crocodiles are opportunistic predators, so humans are not excluded from becoming one of the alternative prey for crocodiles when their natural prey is reducing or even depleted in their habitat (Caldicott et al. 2005).
There are only a few scientific publications that discuss crocodile attack cases in Indonesia. Information about crocodile attacks is often published in mass media which can be accessed through electronic media, newspapers, and direct information from communities around the crocodile habitat. However, there is a limited number of scientific papers that discuss the number of cases of human-crocodile conflicts in general in Indonesia, including the types of attacks and their causes. Limited access to information regarding crocodile attacks is the main problem of difficulties for conflict mitigation. A global crocodile attack database was launched in 2013 which contained data on crocodile attacks in various countries (CrocBITE 2013). Based on information from the database, Indonesia ranked first for crocodile attacks with 1028 cases since 1845 (CrockBITE 2013). Ardiantiono et al. (2015) divide crocodile attack cases based on the data from CrocBITE website into two periods: period I (1845-1890) and period II (2000-2014). In period II, crocodile attack cases were increasing in southern Sumatra, Kalimantan, and Sulawesi. Kalimantan has the most cases of crocodile attacks in Indonesia by 21 cases (CrocBITE 2013).

Kutai National Park with an area of 198,629 ha was established in 1995 based on the Decree of the Minister of Forestry No. 325/Kpts-II/1995. This area has mangroves, rivers, and estuary ecosystems as the main habitat for the saltwater crocodiles (Crocodylus porosus) which is adjacent to the locals' settlement in Bontang City. A populated city with crocodile habitats is more likely to create conflicts. This research aims at mapping the risk points for human-crocodile conflicts in the 
settlements around Kutai National Park and it is expected that this research can be used as a reference in planning conflict mitigation and crocodile conservation in Kutai National Park.

\section{RESEARCH METHOD}

This research was conducted on March - April 2019 and the data were collected from settlements around Kutai National Park (East Kalimantan Province), particularly around Bontang City including Sangkima Subdistrict and Sangatta Subdistrict (East Kutai Regency). Below is a map of the location of research data collection (Figure 1).

The instruments used in this research included Maximum Entropy Modeling (MAXENT) version 3.4.1k, ArcGis 10.5, cameras, GPS (Global Positioning System), and MS. Excel. The materials used in this research included coordinate data of crocodile attacks on humans and crocodile discoveries, Kutai National Park basemap, Digital Elevation Model (DEM), Indonesia geospatial map (Rupa Bumi Indonesia/RBI), and Landsat 8 imagery.

The existence of crocodiles was obtained through direct observation, with the first step by searching for information on the whereabouts of crocodiles from the community around the crocodile habitat. Based on the results of the direct observation, the researchers then traced it based on the information on crocodile sightings. The historical location of the crocodile sightings by the community was then marked with a point using a GPS. Direct observation was also carried out around the waters in Bontang, Sangatta, and Sangkima to get the current crocodile sighting points. Crocodile sighting was also carried out through direct observation during the day when the crocodiles were sunbathing. The observation was carried out using boats on the Sangatta River, while in Sangkima and Bontang City, the observations were done on foot along the riverbanks.

Data of potential conflict were collected through semi-structured interviews with respondents. This method was to provide opportunities for the locals to share their experiences and express their opinions (Pramusanti 2001). The respondents were selected using purposive sampling method according to the criteria and research objectives or with certain considerations (Sugiyono 2010). The criteria were crocodile finders, crocodile attack victims, relatives, and family of crocodile attack victims. The questions for the respondents were the information about the location of the encounter or attack, the form of attack, the time of the attack, the part that was attacked, the activities before the attack, the location of treatment, and the possibility of crocodile attacks.

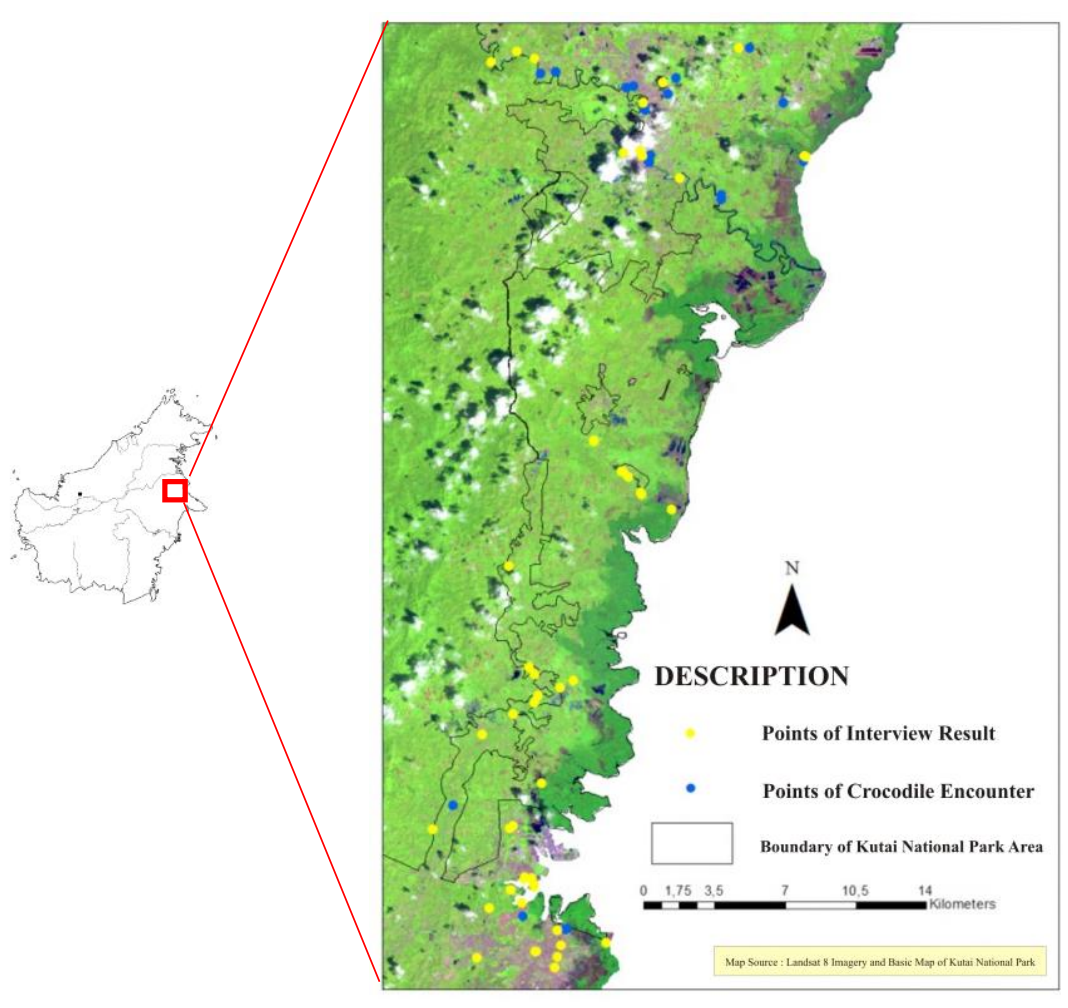

Figure 1 Map of research area on crocodile distribution and risks of human-crocodile conflicts in settlements around Kutai National Park 
Data processing was performed using MAXENT application. The predictive modeling of crocodile distribution in order is presented in Figure 2, then the results of data processing are analyzed descriptively.

The results of predictive modeling of the distribution of saltwater crocodiles were then used as the material to observe areas in settlements around Kutai National Park that had the potential for human-crocodile conflicts through an overlay analysis. Overlay analysis was conducted using the results of predictive modeling of crocodile distribution, with historical points of humancrocodile conflicts and maps of human activities.

The human-crocodile conflict risk mapping was made based on a reclassification of predictive modeling of saltwater crocodile distribution, which was the prediction of high presence with a score of 1 , prediction of moderate presence with a score of 2 , and prediction of low presence with a score of 3 . The classification was done using the natural breaks method or clear breakpoints method. Based on the results of reclassification of predictive modeling of saltwater crocodile distribution, then it was overlaid with the distribution of community activities which were classified into 3 classes of high, moderate, and low activity. High activity is an activity with a distance of less than $1 \mathrm{~km}$ from the crocodile habitat which is given a score of 1 , moderate activity is an activity with a distance of $1-2 \mathrm{~km}$ which is given a score of 2 , and low activity with a distance of $2-3 \mathrm{~km}$ is given a score of 3 . The risk of conflict occurs if human activities are carried out near the crocodile habitat. The risk of humancrocodile conflicts is classified into 3 classes, which are high risk, moderate risk, and low risk. An area is said to be at high risk if the community activities are carried out within a distance of less than $1 \mathrm{~km}$ from the crocodile habitat which is predicted to be high. Moderate risk is an area with community activities carried out 1-2 km from the crocodile habitat which is predicted to be high or moderate, while the low risk is $2-3 \mathrm{~km}$ from the crocodile habitat which is predicted to be high to low (Table 1).

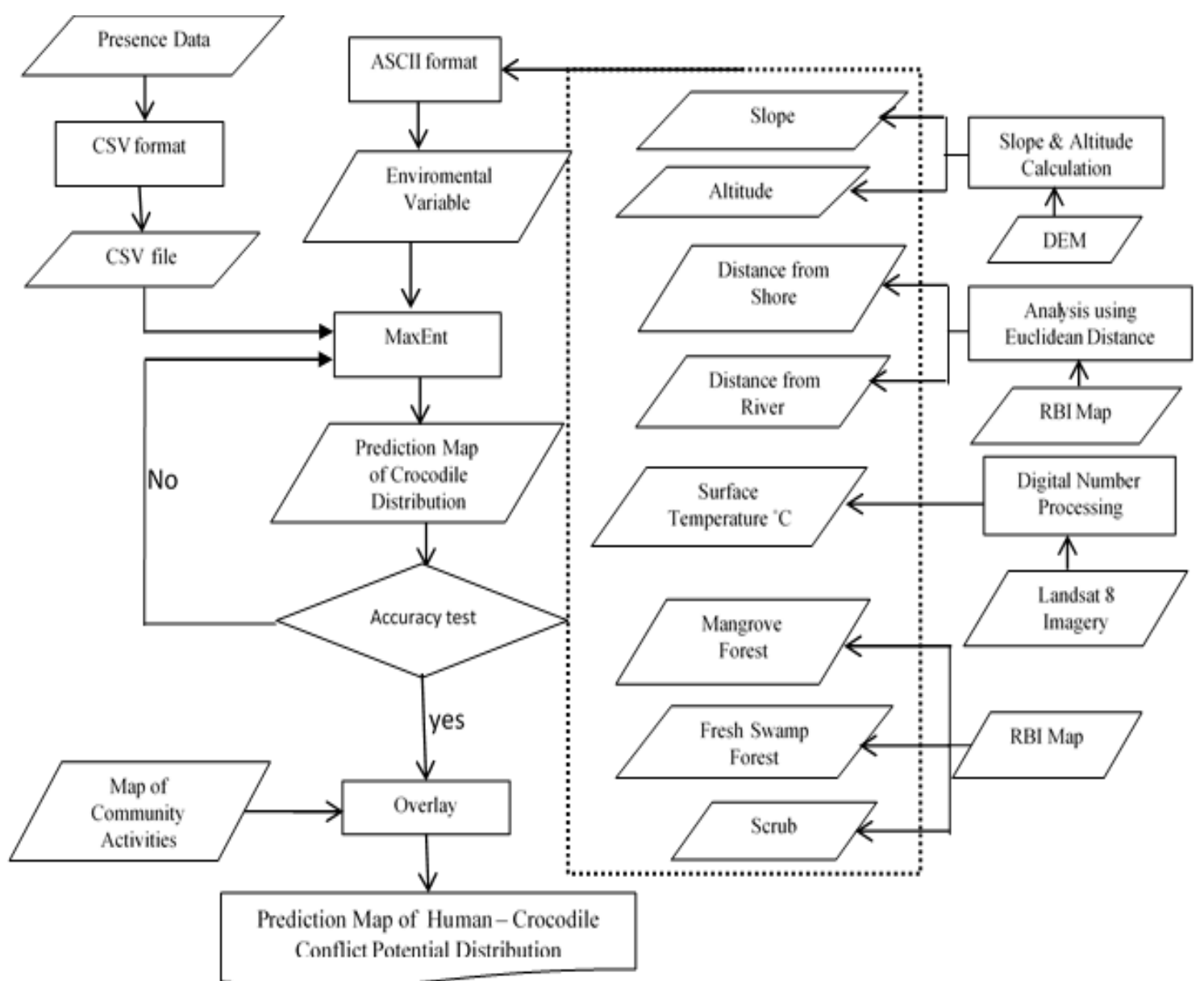

Figure 2 Flowchart mapping of crocodile distribution and risk of human-crocodile conflicts 
Table 1 Classification of level of risk for human-crocodile conflicts

\begin{tabular}{llcc}
\hline & & \multicolumn{2}{c}{ Activity distance $(\mathrm{Km})$} \\
\cline { 2 - 4 } Encounter rates with crocodiles & 1 & 2 & 3 \\
\hline High (1) & 1 & 2 & 3 \\
Moderate (2) & 2 & 6 & 9 \\
Low (3) & 3 & 6 & 9 \\
\hline
\end{tabular}

Description: $1=$ high risk, $2=$ moderate risk, $>2=$ low risk

\section{RESULT AND DISCUSSION}

\section{Prediction of Crocodile Distribution Using Maxent Application}

\section{a. Crocodile distribution}

There were 70 points found based on the results of interview and direct observation of crocodiles found in Bontang, Sangatta, and Sangkima. The majority of points were found in Sangatta area. Crocodiles were found in their main habitats, such as in mangroves, seas, lakes, saltwater, ditches, rivers and ponds. The river is the habitat where crocodiles are mostly found (Figure 3).

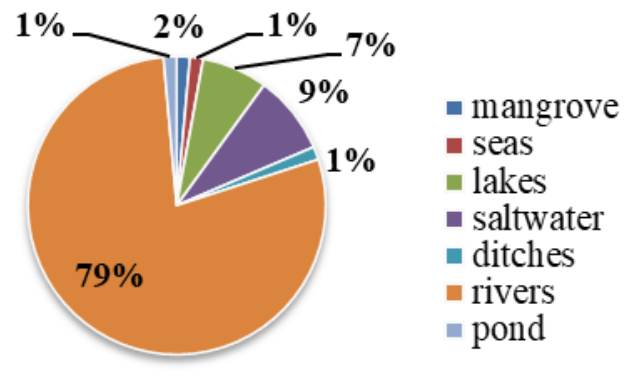

Figure 3 Percentage of crocodiles in several habitats

\section{b. Model accuracy test}

Based on the mean value of the sensitivity and specificity graphs (Figure 4), the AUC (Area Under Curve) value is 0.952 with a standard deviation of 0.013 . The AUC value shows a good result of the modeling evaluation.

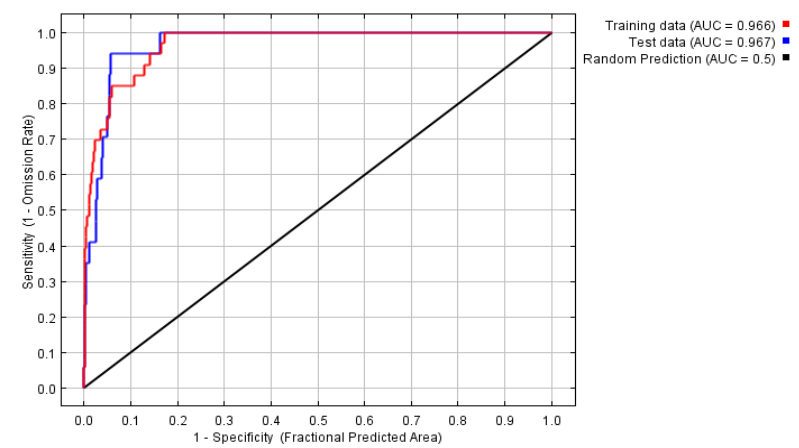

Figure 4 AUC values on sensitivity and specificity curves
The graph of average omission and predicted area (Figure 5) shows high accuracy, as the bias value is quite low. It can be seen from the blue and green lines around the black line which are biased predictions.

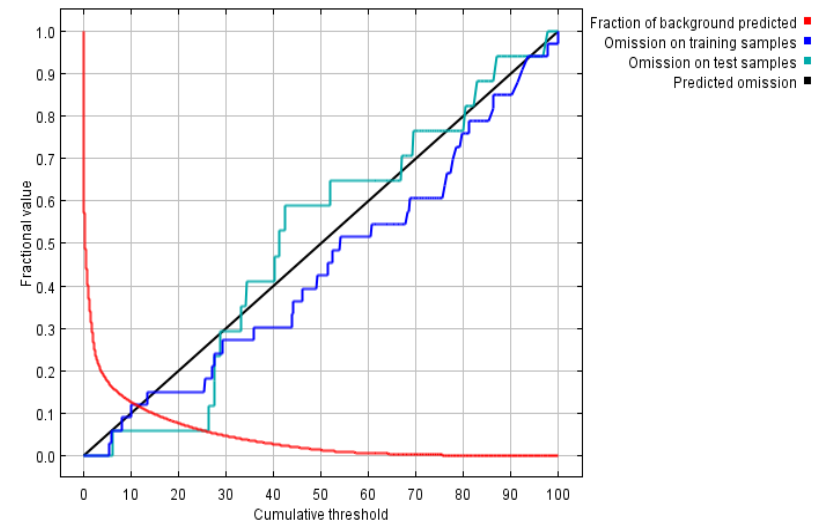

Figure 5 Illustration of omission and protected area curves

Based on the results of AUC test (Figure 6), the environmental variables which give the most influence on performance in assessing the predictive modeling are elevation, distance to shore, and slope. It is because the elevation variable is classified as continuous and has a wide range and range of data. The distance from river variable is the most important variable as indicated by the green line on the curve as the AUC value decreases if the distance from river variable is removed.

The magnitude of the influence of environmental variables on the model is also shown by the table of percent contribution and permutation importance (Table 2 ). The elevation variable is the most influential variable with a contribution value of $55.5 \%$. The model is influenced by variables of river distance, distance from shore, temperature, mangrove forest, swamp, slope, and shrubs.

\section{c. Response curves of environmental variables}

The crocodiles are predicted to live at an altitude less than 50 meters and the slope from 0-5 meters. It is because crocodiles are mostly found in downstream areas, shores, and flat topography in areas where crocodiles are predicted to be high. Non-linear response curves are responses from environmental variables that are not influenced by other variables. The following is an illustration of the elevation response curve and slope response curve (Figure 7). 
(description:

(elevasikutai3=elevation,

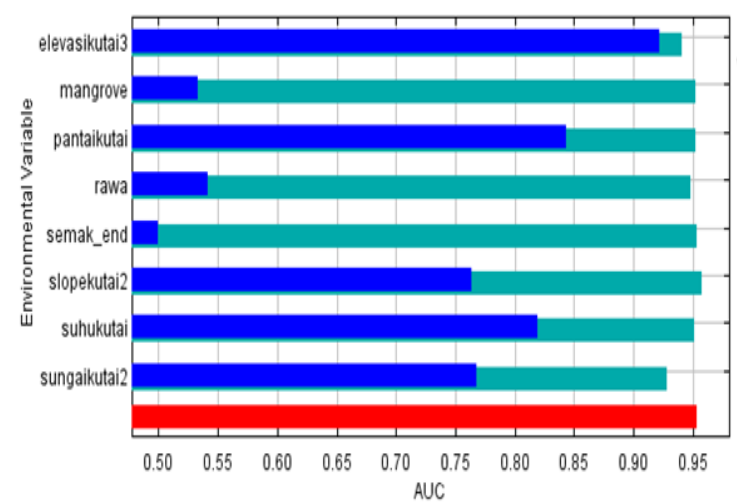

Figure 6 The influence of environmental variables obtained from AUC values

mangrovekutai $2=$ mangrove forest, pantaikutai $=$ distance Withouthvariable from shore, rawakutai= freshwater swamp forest,

With all variables " semakkutai=shrubs, slopekutai $2=$ slope, suhukutai=temperature, sungaikutai $2=$ distance from river)

Based on the response curves, the crocodiles in the mangrove forest and the freshwater swamp are predicted to be high. The higher level of dominance of mangrove forest and freshwater swamp, the higher the prediction of crocodiles. Shrubs are predicted to be equal in both areas with and without shrubs. The comparison of the three predictions for the presence of crocodiles is presented in Figure 8.

Table 2 Comparison of contribution value of each environmental variable

\begin{tabular}{llc}
\hline \multicolumn{1}{c}{ Variable } & Percent contribution $(\%)$ & Permutation importation $(\%)$ \\
\hline Elevation & 55.5 & 71.1 \\
Distance from river & 31.5 & 11.2 \\
Distance from shore & 8.6 & 15.3 \\
Temperature & 2.6 & 0.6 \\
Mangrove & 1.2 & 0.4 \\
Swamp & 0.4 & 0.8 \\
Slope & 0.3 & 0.4 \\
Shrubs & 0 & 0 \\
\hline
\end{tabular}

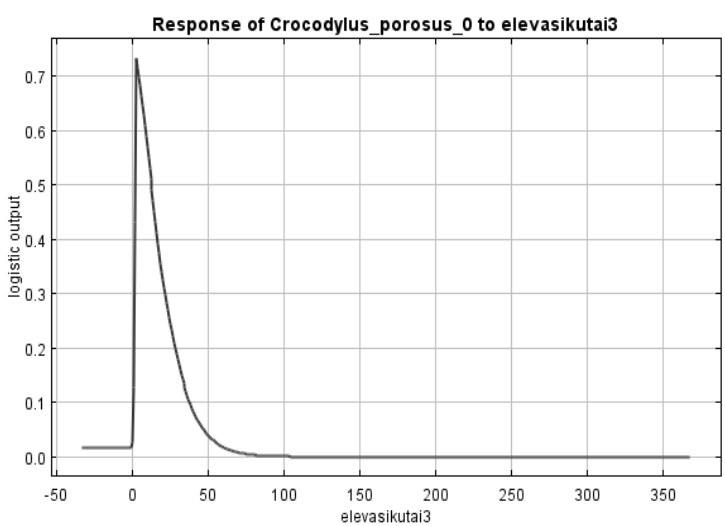

(a)

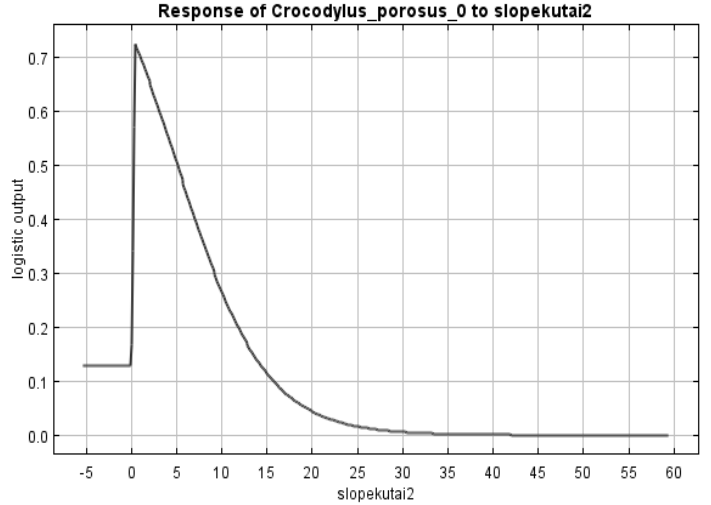

(b)

Figure 7 (a) Elevation response curve (b) Slope response curve



(a) (b)

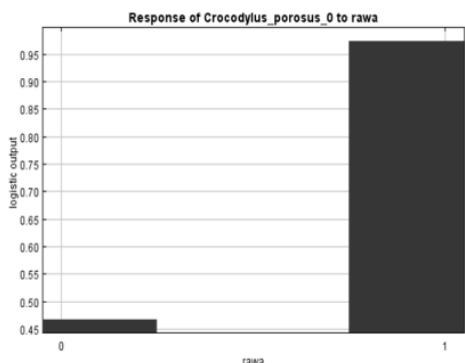

Figure 8 (a) Mangrove response curve (b) Freshwater swamp response curve (c) Shrubs response curve 


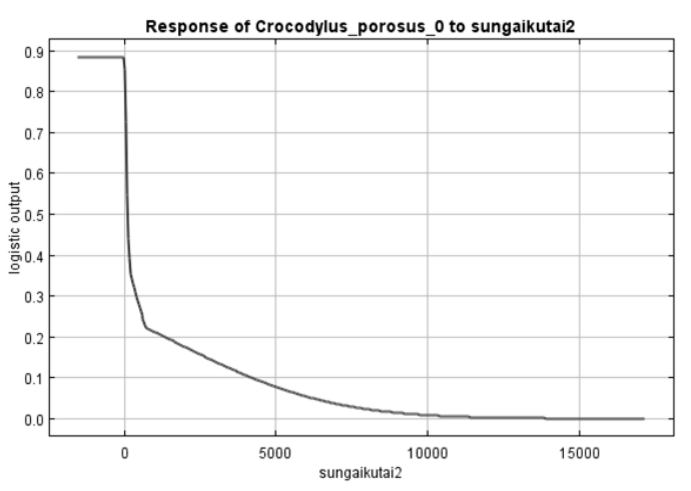

(a)

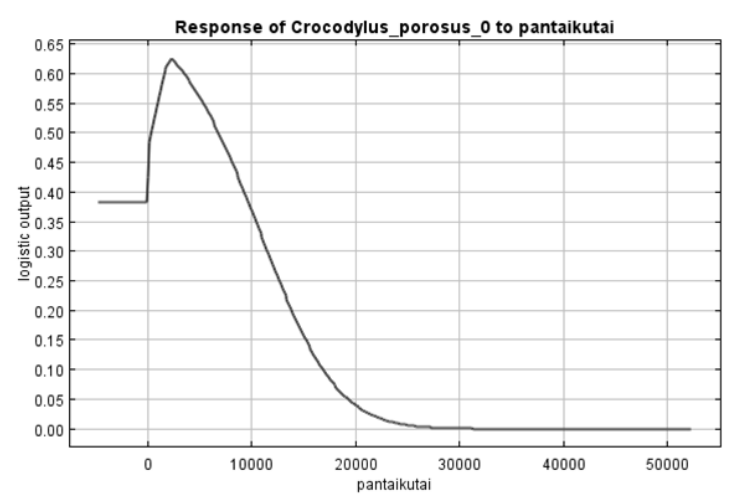

(b)

Figure 9 (a) Distance from river response curve (b) Distance from shore response curve

Based on the response curve of distance from the river and distance from the shore, it is known that crocodiles are predicted to be fewer if the distance is getting farther from rivers and shores. Crocodiles commonly present less than $1 \mathrm{~km}$ from the rivers and shores. The illustration of response curves of the distance from the river and the distance from the coast is presented in Figure 9.

Based on the temperature response curve, it shows that the predicted value for the presence of crocodiles is at a temperature of $26-28^{\circ} \mathrm{C}$ (Figure 10). The temperature is also influenced by topographic conditions which are classified as lowlands. Crocodiles need a temperature that is hot enough for sunbathing since they need to increase their body temperature to metabolize.

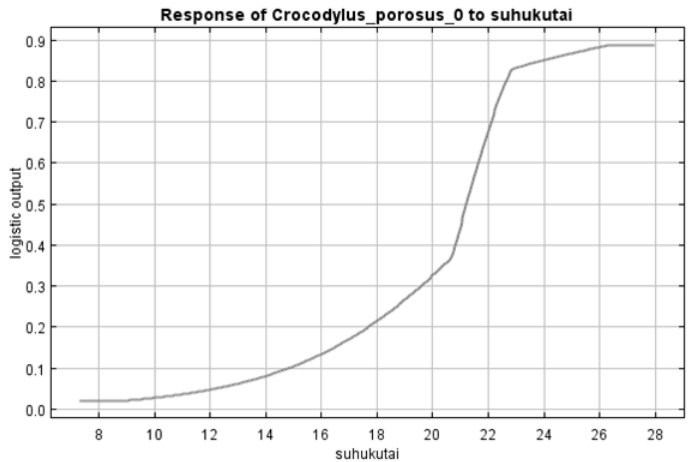

Figure 10 Temperature response curve

The prediction of crocodile population distribution from MAXENT processing shows that elevation from sea level is the most influential environmental variable. It is in line with the results of other studies stating that a good habitat for saltwater crocodiles is characterized by a wide edge of water bodies and lush vegetation for nesting and spawning such as downstream rivers, mangroves, and shorelines (Somaweera et al. 2011), all of which are on the lowlands ranging from 0-100 masl. Moreover, in tropical areas, elevation affects the temperature in crocodile habitat, the higher elevation of an area, the lower the temperature in that area. Crocodile habitat which is classified as lowland makes the temperature in the crocodile habitat warmer. The cold-blooded nature of crocodiles makes them try to maintain their body temperature by sunbathing or seeking shade if their body temperature is too high (Jayson 2002).

\section{d. Prediction of crocodile distribution}

The prediction of saltwater crocodile distribution shows that each location of data collection has crocodiles' presence points. The more an area approaching the red color or scored one on the map, the higher the predicted value for the crocodile's presence at that point. The following is a map of prediction of saltwater crocodile population distribution in settlements around Kutai National Park (Figure 11).

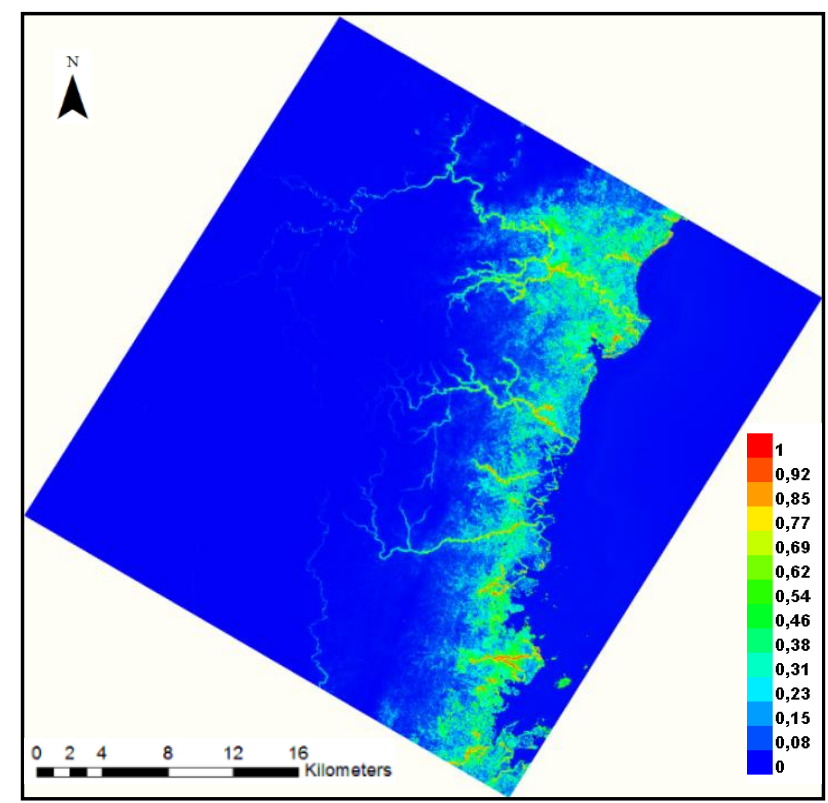

Figure 11 Prediction map of saltwater crocodile population distribution 


\section{Mapping The Risk of Human-Crocodile} Conflicts

\section{a. Crocodile attacks}

Based on the results of interviews about crocodile attacks on humans, 24 cases were reported. The impact of the attack was bite wounds and death. As many as 12 cases of crocodile attacks were recorded that resulted in fatalities or by $50 \%$. Most crocodile attacks on humans occurred in rivers (Figure 12). Based on the observation, community activities in the river and around the river include fishing, bathing, fish farming, and using it as a transportation route. Most cases of crocodile attacks occurred during 2015 - 2017 as many as 6 cases (Table $3)$.

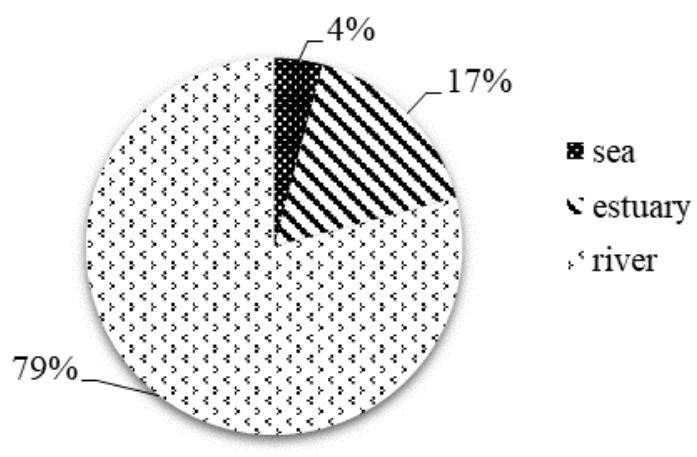

Figure 12 Percentage of crocodile attacks in several places

Currently, the presence of crocodiles around community settlements is considered unsettling and dangerous. Bontang City is the area with the highest awareness of crocodiles compared to Sangatta and Sangkima. It can be seen from the comparison of evacuated crocodiles and wild crocodiles (Figure 13). The data were obtained from the data of Kutai National Park and direct observation.



Figure 13 Comparison of wild crocodiles and evacuated crocodiles in each study location

(Source: data from Kutai Nationa Park and field observation).

Human activities in crocodile habitats trigger conflict between them. Conflict may occur if there is a direct contact between humans and crocodiles which brings negative impacts on crocodiles or humans and even both of them. The increasing human activities and closer settlement to the crocodile habitat is one of the causes of direct contact between humans and crocodiles. Another reason that causes crocodiles to approach community settlements is people's habits that often throw household organic waste, fishery waste, and livestock waste into the rivers. According to Plaza and Lambertucci (2017), rivers that are used as landfills can change patterns of movement, migration, home range, and individual behavior of different species, thereby increasing various types of conflict with humans. Blake (2002) states that crocodiles have a very good sense of smell with the two nostrils at the end of the muzzle that make it easier for them to smell while swimming. These activities can trigger the crocodiles to come to the community settlements.

Table 3. Crocodile encounter in Bontang, Sangatta, and Sangkima and the attacks

\begin{tabular}{|c|c|c|c|}
\hline & Bontang & Sangatta & Sangkima \\
\hline Total respondent & 17 & 24 & 17 \\
\hline $\begin{array}{l}\text { Total crocodile } \\
\text { encounter spots }\end{array}$ & 19 & 21 & 6 \\
\hline Total victim & 3 & 8 & 13 \\
\hline Last attack report & 2015 & 2017 & 2015 \\
\hline $\begin{array}{l}\text { Common location } \\
\text { of attack }\end{array}$ & River, estuary, and sea & River and estuary & River and estuary \\
\hline $\begin{array}{l}\text { Attacked } \\
\text { condition }\end{array}$ & $\begin{array}{l}\text { Injured to the waist, legs, } \\
\text { buttocks, neck and back. No } \\
\text { death reported }\end{array}$ & $\begin{array}{l}3 \text { people were injured and } 5 \\
\text { people died }\end{array}$ & $\begin{array}{l}6 \text { people were injured and } 7 \\
\text { people died }\end{array}$ \\
\hline $\begin{array}{l}\text { Human activities } \\
\text { during the attacks }\end{array}$ & $\begin{array}{l}\text { Fishing, fish farming, traveling, } \\
\text { raising livestock, playing golf, } \\
\text { sea water therapy }\end{array}$ & $\begin{array}{l}\text { Fishing, crossing rivers, } \\
\text { ablution, bathing, selling fish, } \\
\text { repairing pipes, traveling. }\end{array}$ & $\begin{array}{l}\text { Bathing, gardening, } \\
\text { crossing river, washing } \\
\text { motorbikes, fishing. }\end{array}$ \\
\hline
\end{tabular}




\section{b. Mapping of the risk of human-crocodile conflicts}

Based on the classification using the natural breaks method, a map of saltwater crocodile encounters is obtained in Figure 14. Each class has a different range of values: the first class with a range of 0.000000001 0.129217864 (low encounter rates), the second class with a range of 0.129217864 - 0.410456742 (moderate encounter rates), and the third class with a range of 0.410456742 - 0.969133973 (high encounter rates). The class differences are distinguished by the resolution of each pixel. If a figure is approaching number one, it indicates that the location has the most likely presence of crocodiles. The map of encounter rates was then overlaid with the map of community activities. The overlaying results of the two maps found some areas with a high level of conflict potential, which were Sangatta, Sangkima, and Bontang.

The classification results of human-crocodile conflict potential indicate that high potential is obtained in settlements with activities less than one kilometer away from rivers and beaches. The further the distance from rivers and beaches, the potential for conflict is getting moderate and gradually lowering. In addition, activities carried out in areas with a high chance of encountering crocodiles, such as mangroves and freshwater swamps, have a high potential for humancrocodile conflicts (Figure 15).

\section{c. Efforts of Kutai National Park on human- crocodile conflicts}

Kutai National Park, assisted by the community, has tried to overcome the risk of human-crocodile conflicts by evacuating the crocodiles found in their settlements. Crocodiles that are caught are moved to crocodile habitats far from settlements. One of the crocodile release locations is Telaga Bening lake in the Kutai National Park. Telaga Bening lake is chosen as the release location because it is far from settlements and has become a natural habitat for saltwater crocodiles. Apart from being released into their natural habitat, Kutai
National Park also moves the crocodiles to captivity in East Kalimantan, including the Teritip Crocodile Captivity in Balikpapan and Makroman in Samarinda. In addition, Kutai National Park has formed a special team to rescue wildlife, called the Wildlife Rescue Unit (WRU). WRU focuses on saving wildlife including crocodiles. This is in accordance with the Renja KSDAE (2017) regarding National Priority activities in the National Priority Program for the Development of Rural Areas in the form of collaborative management of conservation forests with communities around nonconservation forest areas.

Evacuation is carried out when there is a report from the community. Usually, the evacuation process is assisted by the community. In Bontang area, it is also assisted by the fire department. The rope-snare method is applied to catch the crocodiles. Apart from direct evacuation by WRU, some crocodiles in the settlement are handed over directly by the community. Crocodiles that are caught by the community are usually injured and even dead. It happens because they do not pay attention to the crocodile's safety during the catching process. People use poison as bait or beat the crocodile during the capture. The evacuation process needs to be improved to reduce the potential for conflict. Another effort made by Kutai National Park is the familiarization of wildlife conflicts against community.

The effectiveness of crocodile evacuation carried out by WRU is still unknown. The absence of tagging for the crocodiles that were captured and released again made the crocodiles that were evacuated unable to be traced to their whereabouts after evacuation. The selection for release location of evacuated crocodiles must be considered carefully. According to Walsh and Whitehead (1993), conflicted crocodiles should be evacuated to captivity and should not be returned to wild habitats since $C$. porosus, especially males, have a tendency to return to their hatcheries.

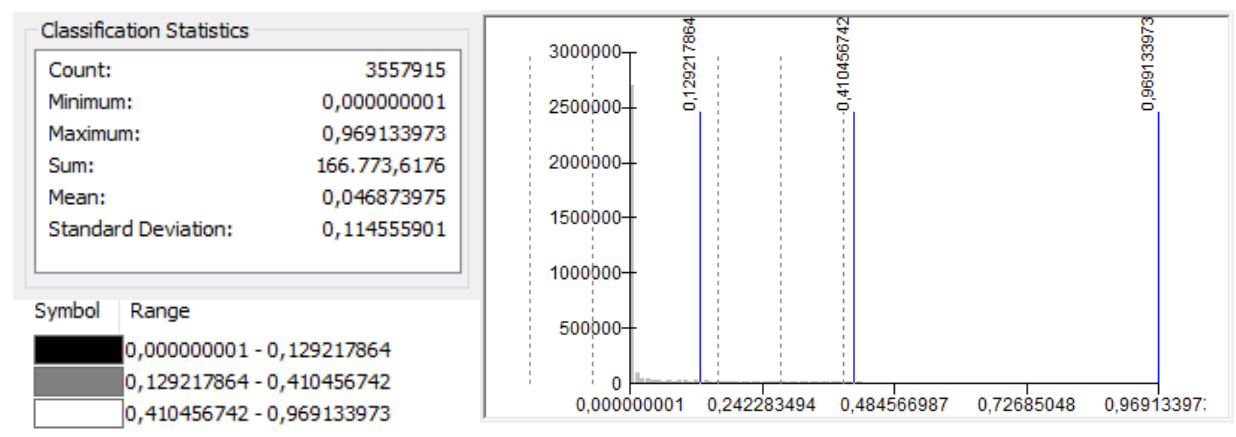

Figure 14 Map classification results of saltwater crocodile encounter rates using natural breaks method 


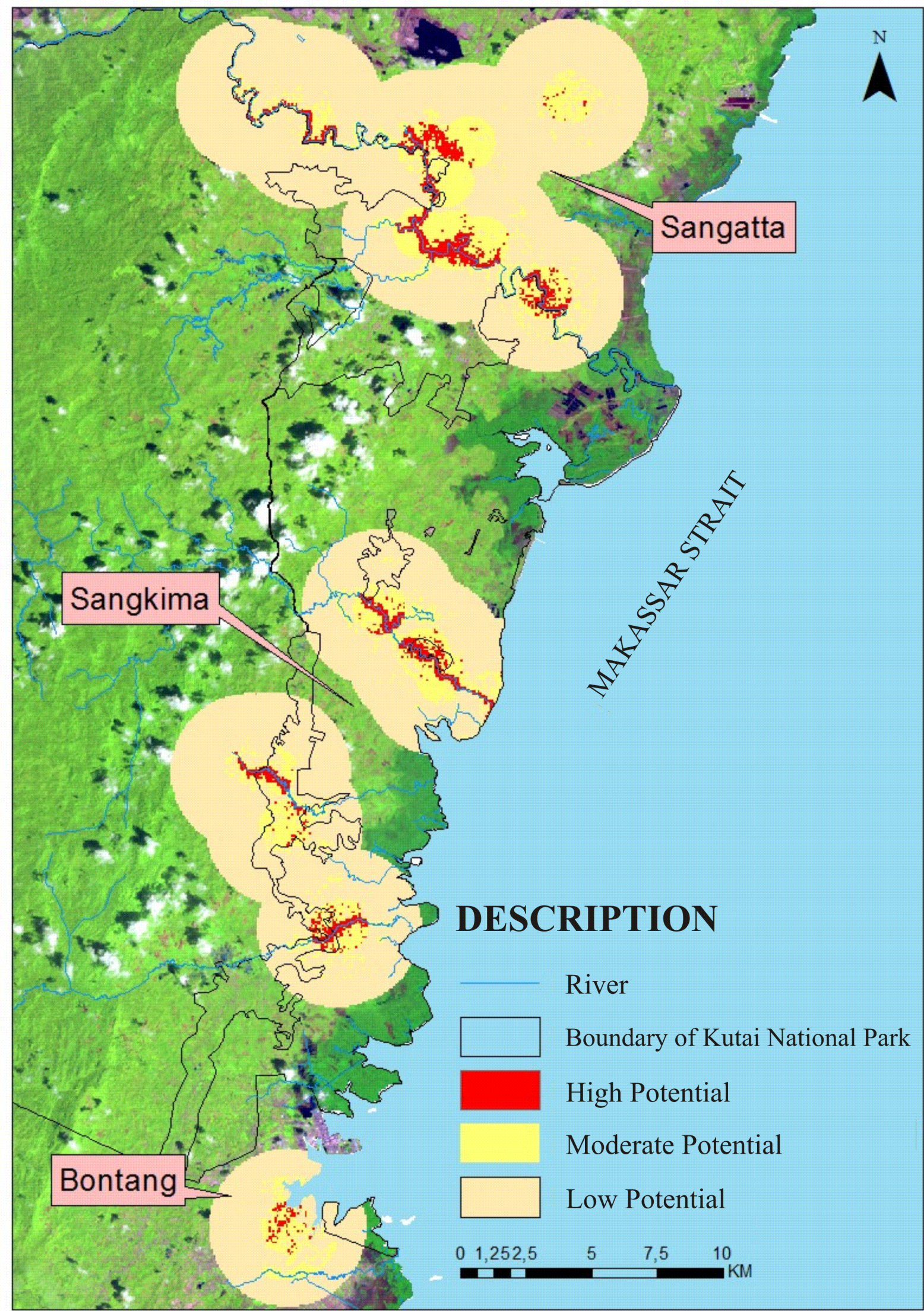

Figure 15 Risk map of human-crocodile conflicts in settlements around Kutai National Park, Kalimantan 


\section{Human-crocodile conflict management}

Crocodile attacks do not only occur in Indonesia, many other countries have experienced similar cases. According to Pooley (2018) in his bibliography, African, American and the Caribbean, Australia and Oceania, Southeast Asian and East Asian countries are experiencing human-crocodile conflicts. Several countries that face human-crocodile conflicts have started to look for solutions to reduce the risks. According to Amarasinghe et al. (2015), the causes of human-crocodile conflict in Sri Lanka include the destruction and loss of natural habitat due to land encroachment by humans. The cause of the conflict in Sri Lanka is not much different from what happened in Kalimantan, especially in Bontang City. Bontang is the most developed city compared to Sangatta and Sangkima. There was a change in land use that occurred in 2014 based on SK .4194/Menhut-VII/KUH/2014 indicating a change in land use which was previously the Kutai National Park area. Development and land-use changes resulted in decreased natural habitat for crocodiles. The solutions pursued by Sri Lanka are habitat restoration, prohibiting human encroachment in river and swamp buffer zones, limiting the issuance of new permits for sand mining near river estuaries (at least $10 \mathrm{~km}$ from river mouths), cleaning up waste and invasive water plants in artificial watercourses to rivers, all of these can be applied in preparing the strategies for conflict mitigation efforts.

According to Fukuda et al. (2014), the public safety program from human-crocodile conflicts consists of two main programs: safety awareness education and evacuation of crocodiles in conflict. Safety awareness education aims at raising awareness of the risk of crocodile attacks, while evacuation of crocodiles in conflict must pay attention to safety. The WRU team of Kutai National Park has been active in promoting animal conflict awareness to schools around the area. Increasing public awareness and awareness of the risk of humancrocodile conflict can be applied through warning boards for the presence of crocodiles. It has not been done optimally by Kutai National Park and East Kalimantan BKSDA (Nature Conservation Agency). Therefore, public understanding and multi-stakeholders cooperation need to be improved in order to create awareness of the importance of coexistence between humans and wildlife.

\section{CONCLUSION}

Human activities in areas with a higher chance of finding crocodiles, especially in mangrove and freshwater swamp ecosystem, increase the risk of human-crocodile conflicts. Settlements around Kutai National Park and Bontang City with activities that are carried out 0-1000 meters away from rivers and beaches have the highest risk of human-crocodile conflicts. Activities that trigger negative interaction between humans and crocodiles include swimming, bathing, fishing, and washing in the river. Kutai National Park has installed warning boards on the presence of crocodiles and evacuated crocodiles in populated settlements.

\section{REFERENCES}

Amarasinghe AAT, Madawala MB, Karunarathna DMSS, Manolis SC, de Silva A dan Sommerlad R. 2015. Human-crocodile conflict and conservation implications of Saltwater Crocodiles Crocodylus porosus (Reptilia: Crocodylia: Crocodylidae) in Sri Lanka. Journal of Threatened Taxa. 7:7111-7130.

Ardiantiono, Sheherazade, Atmadja, RK. dan Wardhani A. 2015. Analisis serangan buaya muara (Crocodylus porosus) di Indonesia melalui eksplorasi database CrocBITE berbasiskan Citizen Science. Inovasi. 24:8-16.

Blake DK. 2002. The Nile crocodile Crocodylus niloticus: capture, care, accommodation and transportation. The capture and Care Manual Ed. Andrew A. McKenzie On line version.

Caldicott DGE, Croser D, Manolis C, Webb G, Britton A. 2005. Crocodile attack in Australia: an analysis of its incidence and review of the pathology and management of crocodilian attacks in general. Wilderness \& Environmental Medicine. (16):143159.

CrocBITE. 2013. The Worldwide Crocodilian Attack Database (terhubung berkala) http://www.crocodileattack.info. [5 January 2019].

Dickman J. 2010. Complexities of conflict: the importance of considering social factors for effectively resolving human-wildlife conflict. Animal Conservation. 13:458 - 466.

Direktorat Jenderal Konservasi Sumber Daya Alam dan Ekosistem. 2017. Rencana Kerja Direktorat Jenderal Konservasi Sumber Daya Alam Dan Ekosistem Tahun 2018. Jakarta: Kementerian Lingkungan Hidup dan Kehutanan.

Fukuda Y, Manolis C, Appei K. 2014. Management of human-crocodile conflict in the Northern territory, Australia: review of crocodile attacks and removal of problem crocodiles. The Journal of Wildlife Management. 78(7):1239-1249.

Jayson EA. 2002. Human-crocodile conflict in Neyyar Wildlife Sanctuary, Thiruvanathapuram. Kerala Forest Research Institute. 349.

Longkumer T, Armstrong JL, Finny P. 2017. Outcome determinants of snakebites in North Bihar, India: a prospective hospitalbased study. J Venom Res. 8:14 18.

Nugraha RT, Sugardjito J. 2009. Assessment and management options of human tiger conflicts in Kerinci Seblat National Park, Sumatra, Indonesia. Mammal Study. 34:141-154.

Plaza PI, Lambertucci SA. 2017. How are garbage dumps impacting vertebrate demography, health, and 
conservation? Global Ecology and Conservation. 12:9-20.

Pooley S. 2018. Croc Digest: A Bibliography of HumanCrocodile Conflict Research and Reports. London: University of London.

Pramusanti E. 2001. Interaksi masyarkat dengan Taman nasional Alas Purwo (Studi kasus di Desa Kendalrejo Kecamatan Tegaldlimo Kabupaten Banyuwangi Propinsi Jawa Timur [Skripsi]. Bogor: Institut Pertanian Bogor.

Ramadhani FS.2018. Interaksi manusia dan reptil berbahaya di Taman Nasional Komodo Provinsi Nusa Tenggara Timur [Skripsi]. Bogor: Institut Pertanian Bogor.

Somaweera R, Webb JK, Shine R. 2011. It's a dog-eatcorc world: dingo predation on the nests of freshwater crocodiles in tropical Australia. Ecol Res. 26:957967.
Subroto H, Lismayanti L. 2017. Snake-Bite with deisseminated intravascular coagulation (DIC) and stage II hypertension. J Med. Health. 1(5):488.

Sugiyono. 2010. Metode Penelitian Administrasi: Pendekatan Kuntitatif, Kualitatif, dan R\&D. Bandung: Alfabeta.

Walsh B, Whitehead P. 1993. Problem crocodiles, Crocodylus porosus at Nhulunbuy, Northern Territory: an assessment of relocation as a mangaement strategy. Wildlife Research. 20:127135.

Webb GJWSC, Brien ML. 2010. Saltwater crocodile (Crocodylus porosus). S. C. Manolis and C. Stevenson, [editors]. Crocodiles. Status Survey and Conservation Action Plan. Third edition. IUCN Crocodile Specialist Group, Darwin, Australia. 99113. 